\title{
Credit Crisis with Focus on Level Three Valuations and FAS 157: Analysis and Recommendations for Change
}

\section{Arber H. Hoti*}

Faculty of Economics, University of Prishtina, Agim Ramadani no. 60, Prishtina, Republic of Kosovo, Serbia

\begin{abstract}
The paper examines the effect of level three valuations and FAS 157 implications on investors, auditors' work valuation disclosures and gives recommendations for improvements based on best practices. The aim of this research is to demonstrate that the fair value measurements should not be suspended. The standards provide for measurement of fair value in all market conditions. Therefore, level 3 measurements or mark-to-model is an answer for many issuers that are not sure how to measure their assets and liabilities at the fair value. The paper concludes that fair value measurement has not caused the current crisis and has no pro-cyclical effect and suggests several recommendations for policy makers and regulators.
\end{abstract}

Keywords: Level three valuations; FAS 157; Financial reporting; Mark-to-mark accounting

\section{Background Information}

\section{Fair value and the crisis}

As the financial crisis started to show up, financial market stakeholders reacted defensively. Namely, they reacted by selling or trying to sell their financial and other assets that were purchased as a result of 'Housing Bubble' [1]. Consequently, a lot of assets, especially real estates, were available for sale on the market, creating an oversupply of houses against demand for the same. As a result, housing prices started to drop, as opposite of the bubble when they went up rapidly. For a high number of individuals who had mortgage loans, house price was lower than what they owed to the banks. Therefore, those individuals were not willing to pay their future installments so banks had to take those houses under their custody and try to sell them as foreclosures.

Downturn in the housing prices did not affect only the real estate market. It had a high negative impact on the financial markets as well. Value of the all types of securities was negatively affected. In particular, Mortgage Backed Securities (MBS), securities whose cash flows are backed by pools of mortgage loans, collapsed and dropped in value. It was a result of bad performance of mortgage loans as there were a lot of subprime loans included in those MBSs. Although there was a higher historical price paid for the MBS, their value sank as no market participant was willing to buy them. As a result, businesses holding such securities had to revaluate them in order to represent the fair value (market value) of those assets in their financial statements.

As the future share price of a business is determined by its current income and the future earnings and cash flows, decrease in the value of the assets held by businesses and inability to produce earnings and positive cash flow was reflected on their share prices. Share prices of the businesses holding MBSs fell down thus making firms look less valuable than before the crisis.

Marking-to-market of the assets that dropped in value does not have a negative effect only to the businesses holding them [2]. It has also a negative effect to all the investors, shareholders and creditors of those particular companies. And, as the shareholders and other security holders reacted by offering their securities for sale, financial markets were flooded by available-for-sale securities. Therefore, decrease in the value of the assets had a chain effect to all financial market participants.
As the financial turmoil was going on, determining the fair value of assets and liabilities in the distressed markets was of a big concern of the financial analysts, auditors and investors.

Determining the fair value of assets and liabilities in a stable financial market would not represent a big challenge. However, determining the fair value of the assets and liabilities in distressed and illiquid markets, it is rather difficult whereas the process faces a lot of challenges. In this regard, FAS 157 sets guidelines on the methods that firms should use when determining the fair value of their assets and liabilities. According to FAS 157, there are three levels in the evaluating hierarchy which are used for measurement of the fair value of assets and liabilities. Further, the FAS 157 hierarchy is described.

\section{FAS 157 hierarchy}

FAS 157 on Fair Value Measurement aim to set standards regarding the asset and liability fair value measurement which would be consistent amongst different industries and business sizes. Its primary objective is that all assets and liabilities shown in the balance sheet should be presented at their fair value.

Based on the information available pertaining to the assets and liabilities, each particular asset or liability may fall under level 1 , level 2 or level 3 valuation techniques. It is the information availability and its reliability pertaining to each asset or liability that decides whether it falls under level 1, level 2 or level 3 valuation techniques.

- Level 1 inputs are all the inputs which can be taken from the active market for the identical assets and liabilities. Such inputs are quoted prices of identical assets and liabilities in the markets where there is enough frequency of transactions and the quoted price is taken as the basis for valuation. However, if there is no

*Corresponding author: Arber H. HOTI, Faculty of Economics, University of Prishtina, Agim Ramadani no. 60, Prishtina, Republic of Kosovo, Serbia, Tel: 38649-373-681; E-mail: arber_hoti@hotmail.com

Received December 07, 2011; Accepted February 09, 2012; Published February 11,2012

Citation: Hoti AH (2012) Credit Crisis with Focus on Level Three Valuations and FAS 157: Analysis and Recommendations for Change. J Account Mark 1:101. doi: 10.4172/2168-9601.1000101

Copyright: (c) 2012 Hoti $\mathrm{AH}$. This is an open-access article distributed under the terms of the Creative Commons Attribution License, which permits unrestricted use, distribution, and reproduction in any medium, provided the original author and source are credited. 
quoted price in an active market for the identical assets and liabilities, than the asset or liability would be evaluated based on level 2 inputs.

- Level 2 inputs are all the observable inputs pertaining to the assets and liabilities to be evaluated. In addition, inputs from the active markets for similar assets and liabilities are used in case there is no active market for the identical assets and liabilities. Further, these inputs are additionally adjusted in order to come up with the fair value of the assets and liabilities. Any significant adjustment needed would move the asset or liability up to level 3 measurement.

- Level 3 inputs are all the inputs which do not fall under level 1 and level 2 inputs. Namely, level 3 inputs are all the unobservable inputs used in order to determine the value of an asset or liability when there is no active market for the identical or similar assets or liabilities and there are no observable inputs available. As a result, business entities should come up with the most suitable valuation model for each asset and liability. These models should reflect the market participant assumptions about the assets or liabilities for which the fair value determination is intended. In these models, they should use all the available information which can be reasonably collected without incurring undue costs.

\section{Reliability of Level Three Measurements}

\section{Weaknesses}

Level 3 valuation models are based on using unobservable information, i.e. firm-supplied estimates in determining the value of an asset or liability. Having considered the current market condition there are several questions that need to be addressed before applying the level 3 measurements or mark-to-model method. The first question is how to actually determine when markets become inactive; second, how to determine if a transaction or group of transactions is forced; third, how, when and to what extent should illiquidity be considered in the valuation of an asset or liability; fourth, how should the impact of a change in credit risk on the value of an asset or liability be estimated; fifth, when should observable market information (e.g. discount rate) be supplemented with unobservable information in the form of management estimates; sixth, how to confirm that assumptions utilized are those that would be used by market participants and not just by a specific entity?

As a result of the level 3 valuations the fair value of an asset or liability is derived using models which are mainly based on fundamental value concept (e.g. discounted cash flow) and the value in-use concept. The inputs used in the level 3 models are based on the assumptions of the market participants would have used in measuring the fair value of those assets or liabilities.

However, there are two main weaknesses of the mark-to model that we have observed. First, the market assumptions on the expected future cash flows may not be the same with the assumptions of the management [3]. Second, what is the adequate discount rate to be used in the model? This question is crucial to the extent that it serves to determine the ratio between two components of the risk associated with the fair value determination i.e. the liquidity risk that is present in distressed markets and the credit risk that is associated with uncertainty of future cash flows. Determination of the discount rate in determining the fundamental value presents a serious problem. If the current risk rate is used to discount future cash flows, the fundamental value tend to converge the present value. On the other hand, if a lower discount rate is used level 3 measured fair values may become a tool for "window dressing" in which the real credit risk is hidden.

As a consequence of the above weaknesses, the level 3 or mark-tomodel is to be used in combination with full disclosure. It ensures that investors and other users of financial statements are made aware of the assumptions used in establishing the fair value of assets or liabilities.

\section{Impact on auditor's work}

Another impact of the level 3 valuation model is on the complexity and volume of the auditors work. We need to stress that auditors should be aware that when they audit clients that are using level 3 valuation models, they should be more cautious when performing audit procedures.

As the level 3 valuation models are based on the unobservable inputs, they involve a lot of judgments and assumptions. Involving judgments in creating valuation models certainly increases the complexity of the work that auditors should perform. In addition to that, auditors should challenge the managements' judgments and assumptions used to determine the value of the assets based on markto-model method.

Moreover, auditors should pay more attention to the information disclosed on the notes to financial statements as they contain all the judgments, assumptions and data used by the management on determining fair value of the assets [4]. As a consequence, auditors will be spending more time on notes to financial statements and will try to test the reasonability behind the assumptions used by the management.

\section{Impact on investors}

It is the general consensus among the investors that the application of the fair value measurement concept in financial statements as provided in FAS 157 should not be suspended. Vast majority of investors share the opinion that the fair value allows them to assess the value of their investments and take necessary decisions. Most of the investors also do not think that the fair value measurement has a pro-cyclical effect on the market. In other words fair value measurement is only a reflection of economic events that occurred with relation to financial markets (FASB). Therefore, the fair value measurement has actually helped them in taking investment decisions. However in the light of level 3 model measurements the investors expect more transparency in disclosures i.e. full transparency with regard to assumptions used in determining the fair value using this mark-to-model method. Full disclosure is important especially having in mind the current market situation that for the most of market participants is considered to be an inactive or distressed. Financial statements need to incorporate the assumptions used for building the model and clear definition of risk components [5]. The investors expect clear picture on the measurement of the liquidity and credit risk incorporated in the markto-model fair value measurement for assets and liabilities. Besides, full disclosure in the notes to the financial statements it is expected from the management of the issuers to analyze and further disclose details on the inputs used in applying mark to model measurement method in the annual MD\&A.

\section{Level three valuation disclosures}

FAS 157 require issuers to annually disclose the inputs and techniques used to measure fair value. It also requires disclosure of the discussions regarding the changes in the inputs and techniques in case any change occurred during the reporting period. We deem 
the required disclosure as a value relevant variable [6] because users of the financial statements properly place their primary reliance on the published financial statements. Besides investors, financial analysts as well predict future earnings based on issuer's published financial statements [7]. However, we believe that current disclosures requirements are not be sufficient to address the issue of inactive markets, where level 3 valuations must be used by issuers who hold "hard-to-value" assets or liabilities (AICPA). Our opinion is based on the following facts:

- FAS 157 do not require disclosure of the controls in place regarding the valuation of assets or liabilities in financial statement (notes or MD\&A). As a consequence some of the big financial institutions such as AIG, Morgan Stanley, etc, have disclosed restatements [8] of fair value measurements due to the lack of controls in place associated with these measurements. Restatements of the financial statements may have great influence on investors and analyst. As a result they will decrease their expectations about the companies earning quality (loss of credibility on the fair value process) consequently affecting company's stock price.

- FAS 157 also do not require companies to perform sensitivity analysis of fair value estimates and disclose them into the notes of financial statements, respectively in the risk management part. Since fair value estimates rely on input assumptions, the fair values derived are highly sensitive to potential changes in some of the assumptions made. The disclosure of these analyses is highly important for investors, financial analysts and other interested parties. It provides them with the additional information which helps measure the real effect that change in these inputs (e.g. increase or decrease in the discount rate) has on the overall performance of the issuer. Such disclosures should be mandated as it increases the reliance that current and potential investors have on the mark-to-model valuations.

\section{Recommendations}

Having considered the need for additional application guidance for determining fair value in inactive markets using the level 3 measurements, the standard setter should consider the following:

- Additional requirement for full disclosure and presentation of the assumptions used in the model when determining the fair value and their effect in financial statement.

- Requirement for explicit quantification of risk components used in mark-to-model measurement i.e. liquidity vs. credit in order to ensure full transparency for financial statements users.

- Consider suspension of application of the OTTI for a limited period of time (in our opinion one reporting period) for assets and liabilities measured at fair value due to uncertainties in market i.e. there is no possibility to estimate the liquidity risk and credit risk and use level 3 measurement in order to protect the companies from having to book OTTI that may be caused by illiquidity. This measure has to be implemented carefully, accompanied with full disclosure by issuers and has to be closely monitored by SEC for compliance to avoid any "window dressing" tendency.
- It is proposed that some of the reservation to adopt Level 3 of FAS 157 comes from references in the standard to "management judgment." But, as discussed earlier in this paper, it is recommend that FAS 157 be revised and include two additional disclosure requirements which will increase the quality of information to the public regarding level 3 measurements. Disclosure of controls regarding fair value measurements should be mandatory for all firms holding assets and liabilities at fair value which are significant to the financial statements. Lastly, disclosure of the effect of alternative assumptions used in valuation models for unobservable inputs. In other words, issuers should disclose the results of the sensitivity analysis, which currently are mandatory for companies following IFRS 7 [Appendix 1].

\section{Conclusion}

In this research I considered the market conditions, weaknesses of the mark-to-model, the effect on users of financial statements as well as possible improvements to be implemented by standard setters. As a conclusion, it is considered that the fair value measurements should not be suspended. The standards provide for measurement of fair value in all market conditions. Therefore, level 3 measurements or mark-to-model is an answer for many issuers that are not sure how to measure their assets and liabilities at the fair value. Therefore, fair value measurement has not caused the current crisis and has no pro-cyclical effect. It only reflects the substance of the economic events and transactions in the financial statements. Blaming the fair value measurement for reflecting the bad news is not correct. Calls for suspension of the standards requiring use of fair value would only deepen the crisis and temporarily hide losses. Even though this temporary relief would help some market participants, it would diminish the transparency which in long run would discourage the investors. That would, in turn, cause greater crisis with enormous threats to global economy what we may call the "the calm before the storm".

\section{References}

1. Dean Baker (2008) The Housing Bubble and the Financial Crisis. Real-world economic review 46: 73-81.

2. DAVIS-FRIDAY P. Y., LIU C.-S., MITTELSTAEDT H. F (2004) Recognition and Disclosure Reliability: Evidence from SFAS No. 106. Contemporary Accounting Research 21: 399-429.

3. IMHOFF E.A., LIPE R.C., WRIGHT D. W (1991) Operating Leases: Impact of Constructive Capitalization. Accounting Horizons 5: 51-63.

4. Robert Libby, Mark W. Nelson, James E. Hunton (2005) Recognition v. Disclosure and Auditor Misstatement Correction: The Cases of Stock Compensation and Leases.

5. Patricia M. Dechow, Linda A. Myers, Catherine Shakespeare (2009) Fair Value Accounting and Gains from Asset Securitizations: A Convenient Earnings Management Tool with Compensation Side-Benefits. 49: 2-25.

6. Alan Reinstein, Gerald Lander,Stephen Danese (2005) Consolidation of Variable Interest Entities: Interpretation No. 46. Stamford, CT: FASB

7. Mark W. Nelson, John A. Elliott, AND Robin L. Tarpley (2002) Evidence from Auditors about Managers' and Auditors' Earnings Management Decisions. The Accounting Review 77: 175-202.

8. http://www.ft.com/cms/s/0/06245606-e99c-11dd-9535-0000779fd2ae.html

9. American Institute of Certified Public Accountants (AICPA) (2004) AU Section 312: Audit Risk and Materiality in Conducting an Audit. New York, NY: AICPA 